DOI: https://doi.org/10.34069/AI/2021.46.10.24

Abramenko, I., Boyeva, K., Dubskaya, O., Gubachev, V., \& Murzin, A. (2021). Innovative approaches to plastic waste recycling using the example of the textile industry. Amazonia Investiga, 10(46), 234-243. https://doi.org/10.34069/AI/2021.46.10.24

\title{
Innovative approaches to plastic waste recycling using the example of the textile industry
}

\section{Инновационные подходы по переработке пластиковых отходов на примере текстильной промышленности}

Received: September 10, 2021

\begin{abstract}
Nowadays, pollution problem is very acute all over the world. Significant reduction of negative impact of pollutants on humans and the environment, as well as the improvement of a number of environmental and economic indicators can be ensured by the achievement by the countries of a proper level of development in the waste recycling issue. Within the framework of this article, the problems of plastic waste processing and the introduction of innovative solutions for their disposal and recycling are considered. The research aims to study the innovative ways of plastic waste recycling and assess the feasibility of their use in the textile industry. In the course of the study, the experience of introducing innovative environmentally-oriented technologies for plastic waste recycling was studied, the main approaches and strategies for introducing environmental innovations, as well as priority areas of environmentally oriented innovations in production, were considered. The main result of the study includes reasonable proposals for the implementation of plastic waste recycling technology in the production of textiles.
\end{abstract}

Accepted: October 30, 2021

\author{
Written by: \\ Ivan Abramenko ${ }^{93}$ \\ https://orcid.org/0000-0002-5627-8517 \\ Kseniya Boyeva94 \\ https://orcid.org/0000-0002-8651-7339 \\ Oksana Dubskaya ${ }^{95}$ \\ https://orcid.org/0000-0002-6561-7867 \\ Vladimir Gubachev ${ }^{96}$ \\ https://orcid.org/0000-0002-1964-5816 \\ Anton Murzin ${ }^{97}$ \\ https://orcid.org/0000-0001-9190-8919
}

\footnotetext{
${ }^{93}$ Head of the Department, Russian Scientific Research Institute of Land Improvement Problems, Russia.

${ }^{94}$ Senior Lecturer, Southern Federal University, Russia.

${ }^{95}$ Associate Professor, Southern Federal University, Russia

${ }^{96}$ Associate Professor, Kortunov Novocherkassk Engineering and Reclamation Institute - branch of Don State Agrarian University,

Platov South-Russian State Polytechnic University (NPI), Russia.

${ }^{97}$ Associate Professor, Southern Federal University, Don State Technical University, Russia.
} 


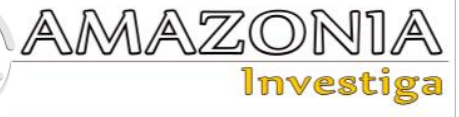

Keywords: plastic waste recycling, innovative technologies, textile production.

явились обоснованные предложения по внедрению технологии переработки пластика для использования в производстве текстиля.

Ключевые слова: переработка пластика, инновационные технологии, производство текстиля.

\section{Introduction}

World experience shows that sustainable economic growth is enforceable only with active innovation based on the use of the achievements of scientific and technological progress (Buciuni $\&$ Pisano, 2021). The environmental innovation concept appeared at the end of the last century. Environmental innovations are the innovations able to reduce the negative impact on the environment, when introduced and used in various types of economic activities. It is worth noting that this definition includes both new and improved technologies and products that minimize environmental damage (Fadhilah \& Ramayah, 2012).

Environmental innovations can be classified into two types. The innovations of the first type are aimed at the involvement of natural productive forces and natural resources in production and more efficient and rational use of them. The innovations of the second type are aimed at tightening of the measures to prevent environmental pollution, which in turn incite the development, implementation and investment in the production of eco-technology and ecotechnologies (Kim et al, 2021). The introduction of innovative technologies for waste plastic recycling belongs to the first type of environmental innovation. The introduction of innovative plastic recycling technologies contributes to the achievement of positive economic, environmental and social effect (Ullah \& Nasim, 2021).

Annually, millions of tons of plastic are produced worldwide, most of which is not recycled. The share of plastic waste that has never been recycled is $91 \%$, about $12 \%$ of all plastic waste was incinerated, while the remaining $79 \%$ are being accumulated either in landfills or in the natural environment (Parker, 2018). Despite the fact that plastic was invented at the end of the 19th century, the rapid growth of its world production was observed in the second half of the last century. 8.3 billion tons of this material have been produced in the world since about 1950 (Zhang, 2017). According to various sources, the decomposition period of plastic is 200-500 years, upon falling into the soil, plastic waste breaks down into small particles and releases into the environment the chemicals added to it during production. Microbeads of plastic and its chemicals seep through groundwater to nearby water sources, often leading to mass extinction of fauna (Soltani et al, 2021). Moreover, plastic accounts for up to $80 \%$ of all waste in the oceans. Under the influence of sunlight, it breaks down into small particles, microgranules of plastic accumulate persistent toxic substances on their surface (Chaturvedi et al, 2020).

The existing methods of plastic waste recycling can be conditionally divided into three groups (Ishalina et al, 2015): mechanical, chemical, and thermal. The first group includes mechanical recycling which is one of processing methods. This is a classic recycling method, based on shredding of plastic waste with the aim of its further recycling. Recycling plastic by chemical methods can be carried out by methods of hydrolysis and methanolysis.

Hydrolysis is a processing method based on the splitting of plastics with aqueous solutions of acids under the action of high temperatures. Methanolysis is a method of plastic recycling based on deep polymerization (cleavage) with methanol. The third group includes pyrolysis (thermal destruction). This method of plastic recycling is a controlled process of thermal decomposition of raw materials, which does not require preliminary thorough sorting and cleaning.

The fight against garbage pollution in the world has been going on for several years. Each country has developed its own rules for the collection and disposal of waste. In Europe, Germany recycles waste most successfully. For several decades in a row, since about 1980 , this country has been practicing segregated collection of garbage, moreover, at the state level, norms have been established according to which a fine is provided for waste thrown out in the wrong place. After collection, the bulk of waste is sent for recycling. Moreover, Germany is currently the first country to develop market regulations for the disposal 
and recycling of plastic waste (Patel et al, 2000; Schüch et al, 2016; Steinhorst \& Beyerl, 2021).

Another European country that practices segregated waste collection is France. For example, there are a large number of containers with different markings for certain types of waste on the streets of French cities. In May 2018, the European Commission published the rules according to which toxic plastics must be replaced with alternative materials. While the country lags behind Germany and the Netherlands in recycling of the plastics produced by it, the authorities have already banned singleuse plastic bags in local supermarkets to fulfill their promise to use only recycled materials throughout France by 2025. In recent years, a socially responsible concept of consumption has been gaining popularity in France, based on the principles of democracy, social utility, mixing of resources and their common use. For example, in Paris, this approach has led in practice to the creation of fifteen specialized centers for the collection and re-sale of various products. Likewise, as in other European countries, penalties are imposed for violating garbage collection rules in France (Defeuilley \& Lupton, 1998; Moinard et al, 2021).

Sweden can be considered one of the most successful countries in waste recycling. Today, the overwhelming majority (over $80 \%$ ) of waste in this country can be recycled, moreover, there is a practice of importing waste from other countries. Recycling and incineration have become effective waste management practices, helping the country to dramatically reduce the amount of waste that ends up in landfills. These efforts are also helping to reduce dependence on fossil fuels. The use of energy from waste recycling can cover a significant part of the needs of the Swedish population (Mattsson et al, 2003; Hage et al, 2009; Salmenperä, 2021).

According to the EPA, about 30 million tons of non-recyclable plastic are produced annually in the United States. Each state in the country is developing its own solutions to the problem of plastic pollution. For example, in New York, since 2019, a ban has been introduced on the sale of food in disposable polystyrene food containers. At the federal level, the USA has been implementing the RRR ("reduce, reuse and recycle") program, which means reducing consumption, reusing and recycling. The main goal of this program is to increase waste recycling and reduce the number of landfills. Secondary raw materials in the USA are recycled at more than 550 factories, and the number of people employed in waste processing reaches 1.5 million, the turnover of this industry is about 250 billion USD per year. Over the past 30 years, the level of waste recycling in the country as a whole has tripled and exceeded 34\% (González-Torre et al, 2003; Otegbeye et al, 2009; Lonca et al, 2020).

Japan is one of the few countries with a waste reduction, reuse and recycling initiative. In this country, as well as in the abovementioned ones, segregated waste collection is exercised. More than $85 \%$ of collected PET bottles are reused in production, this figure is on average higher than that of the USA and EU countries. Today, it is this country that is the world leader in plastics processing (Matsumoto, 2011; Kinnaman et al, 2014; Honma \& Hu, 2021).

China is another Asian country where the issue of waste collection and disposal is acute. Although the social responsibility of people with regard to waste collection in this country is not very developed, data from the Ministry of the Environment of the PRC indicate that about $90 \%$ of China's waste is disposed of by incineration or dumping, and the recycling industry is the second largest after the agriculture industry in job creation in the country (Wang et al, 2020; Kumamaru \& Takeuchi, 2021).

The world practice of recycling is as follows. The most common waste collection method is segregated collection, the rules of which are individually established at the legislative level in each country. Most developed countries are considering the possibility of switching from traditional waste management options in the form of incineration and disposal, to modern ones, involving the transition to waste-free production: waste processing and recycling (Ragaert et al, 2017; Lee et al, 2021). There is also the following trend in the successful implementation of environmental programs: the more socially oriented the population, the higher the indicators characterizing the level of development of waste processing technologies in the country (Pérez-López et al, 2016).

Thus, the experience of economically developed countries shows that the problem of waste recycling can be solved only with the use of comprehensive measures: the simultaneous regulation of all mechanisms and stages of the movement of waste from the source through transportation to the points of storage, processing or disposal. Waste management programs have been developed and are operating at the government level in almost all economically 


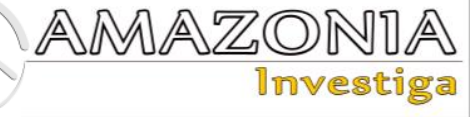

developed countries. The best way to waste processing is considered to be recycling, landfilling or incineration is not feasible either from an economic or environmental point of view. One of the priority tasks is the creation of integrated waste management systems. The basis of the concept of integrated waste management is that waste consists of various components, which ideally should not be mixed and disposed of separately from each other, but should be recycled in the most economical and environmentally friendly way.

The purpose of this research is to study innovative ways of plastic waste processing and assess the feasibility of their use in the textile industry. In the course of the study, the experience of introducing innovative environmentally-oriented technologies for plastic processing was studied, the main approaches and strategies for introducing environmental innovations, as well as priority areas of environmentally oriented innovations in production, were considered.

\section{Literature Review}

Currently, two main areas in the field of innovation in plastic waste recycling are developing, namely: plastic waste processing and recycling. In the first case, it is the receipt of new materials and substances from plastic, in the second is the creation of new things from plastic. The examples of innovative ways of plastic waste recycling are considered below.

The "PETase" enzyme was created by the international team of scientists while studying the bacteria "Ideonella sakaiensis". This enzyme was discovered in 2016 in Japan. With this discovery, polymers can be decomposed into monomers and made back into plastic products. This process removes oil from the polymer production chain (Chen et al, 2020).

The German concern BASF has proposed a new method for the chemical processing of plastic waste. The processing process is as follows: garbage is collected and delivered to a processing plant, where synthetic oil or gas is obtained from it, then, the raw materials are split at a temperature of about 850 degrees, resulting in ethylene and propylene used for the production of various chemical products. These raw materials can also be used to re-manufacture plastics. The advantage of this technology is that any plastic can be recycled, even one that is usually not recyclable (BASF, 2021).
The American company Envion has released a ready-made installation able to get synthetic oil from plastic waste. The technology developers claim that 3-5 barrels of synthetic oil can be obtained from one ton of plastic waste, and in a year such a plant can process 10,000 tons of plastic waste, producing 30-50 thousand barrels of synthetic oil (Mastellone, 2019).

Chinese and American scientists have developed a new way of disposing of plastic waste, making it possible to obtain three different substances from plastic, none of which are plastic. The recycling process for plastic waste consists of two stages. At the first stage, the waste is placed in a catalyst containing molecules containing an iridium atom. Ultimately, the hydrogen compounds are detached from the polyethylene. In the second stage, the "purified" material is placed in a catalyst based on rhenium and aluminum atoms with the addition of petroleum compounds. After all chemical reactions, polyethylene decomposes into three types of constituents: chemical compounds, wax substances and diesel fuel (Latham, 2021).

Italian scientists have developed a new way of recycling plastic waste. Gr3n has developed a mechanism for the isolation of pure polyethylene terephthalate (hereinafter - PET). This mechanism is called "depolymerization" (the process of cleavage of polymers under the influence of microwaves). From this liquid, pure polyethylene terephthalate is obtained, which is then used to make plastic or synthetic fabrics (Rickert et al, 2020).

Thus, the methods of plastic utilization being developed are based on obtaining other substances and materials from it, which can be used in the future. The use of innovative solutions in this matter will create a closed cycle for the production and processing of polymers.

Recycling of plastic bottles is also a promising direction for the development of industrial production. Today, there are a large number of applications for PET recyclable materials in many industrial sectors. The processing line allows using the finished material both as an additive and as the main material for the manufacture of new products. Already today, containers for chemicals, furniture, fabric bases for the production of textiles, clothing and carpets, car parts, noise insulation materials and much more are made from recycled plastics.

For example, Volvo has long announced that some of the elements of new cars would be made 
of recycled plastic (Kantz, 2000). To date, a hybrid crossover has been produced, equipped with recycled parts, which are no different in quality from parts made of ordinary plastic.

Interesting use of plastic waste was invented in the Netherlands. A plastic cover for the roads as a replacement for the usual asphalt was invented there. The main advantage of such roads is their high strength and resistance to external influences, as well as ease of installation and dismantling (Zhang et al, 2020).

The use of recycled plastic in $3 \mathrm{D}$ printing is another promising trend for the development of the recyclable materials market. In 2015, the Argentine startup B-pet introduced technology for recycling plastic into a material used in 3D printing. Later in 2017, the Dutch design team The New Raw 3D printed a bench using recycled plastic bottles and bags. Subsequently, the company began mass-production of outdoor furniture from recycled polymers (Peeters et al, 2019).

Another promising area for using recycled plastics is fuel production. Thus, oils, waxes, solid fuel for stoves, combustible gas and gasoline can be produced using thermal decomposition (pyrolysis) (Kumamaru \& Takeuchi, 2021).

The fashion industry also uses the achievements of modern technologies in the field of recycling plastic waste and the production of clothing from them. Recycled plastics are used to make clothing and fabrics. With the help of new technologies, clothes can be produced from garbage, thus both environmental and economic problems can be solved by reduction of production costs when using secondary raw materials. (Provin et al, 2021).

Thus, plastic, even after processing, remains a fairly versatile material that can be used in various industries.

\section{Methodology}

The purpose of this research is to study innovative ways of processing plastic waste and assess the feasibility of their use in the textile industry. In the course of the research, the experience of introduction of innovative environmentally-oriented technologies for plastic processing was studied, the main approaches and strategies for introducing environmental innovations, as well as the priority areas of environmentally oriented innovations in production, were considered.

The following problems should be solved to achieve the goal of the research:

1) to review the experience of waste collection and recycling in different countries;

2) to review the innovative technologies for waste processing and recycling (plastic waste);

3) to assess the implementation of innovative technologies for waste processing (plastic waste) in Russia using the example of the textile industry.

A scientific literature review method was used to review the experience of waste collection and recycling in different countries and to review the innovative technologies for waste processing and recycling. The implementation of innovative technologies for waste processing (plastic waste) in Russia, using the textile industry as an example, was assessed by comparing the efficiency of mechanical recycling of plastic and recycling of plastic using a microwave reactor.

The article examines the economic benefits of implementing innovative technology for waste disposal and recycling, as well as the energy savings of implementing the said technology. The article also considers the necessary for the introduction of innovative technologies for plastics recycling in the textile industry.

\section{Results and Discussion}

Innovative strategies developed by the companies involve dramatic changes in production technologies. On the one hand, the successful functioning of an organization in the areas that have been mastered depends on the effectiveness of the developed and implemented innovations, on the other hand, the possibility of entering new directions. The main goal of introduction of innovations in the production of textiles and clothing is to reduce production costs by saving raw materials and energy, as well as the negative impact of plastic production on the environment. This is especially true in the context of the sanctions confrontation between Russia and developed countries, when the strategic development of a company depends on many factors, as well as on political risks (Nusratullin et al, 2020; Nusratullin et al, 2021).

Previously, the development of Italian scientists in the field of plastic waste processing was cited. $\mathrm{Gr} 3 \mathrm{n}$ has developed an innovative microwave 


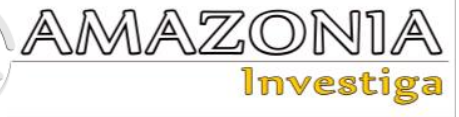

alkaline hydrolysis process that provides a costeffective PET recycling process that can be commercialized. This new process has the potential to change the way PET is recycled globally, with enormous benefits for both the recycling industry and the entire polyester value chain.

The process itself is a combination of mechanical and chemical processing in one generator (DEMETO project). According to the developers, complete depolymerization takes 10 minutes, which ensures the continuity of the processing process. Moreover, any plastic waste is recycled, even the impure one (impure transparent bottles with labels, caps, etc.) unlike in traditional recycling. The quality of the recycled material is the same as that of the raw material. In order for the installation to work, water and electricity are needed. Plastic waste in the form of flex (shredded plastic) is loaded into a microwave reactor, where it is processed into pure PET. The technology is described in more detail in Figure 1.

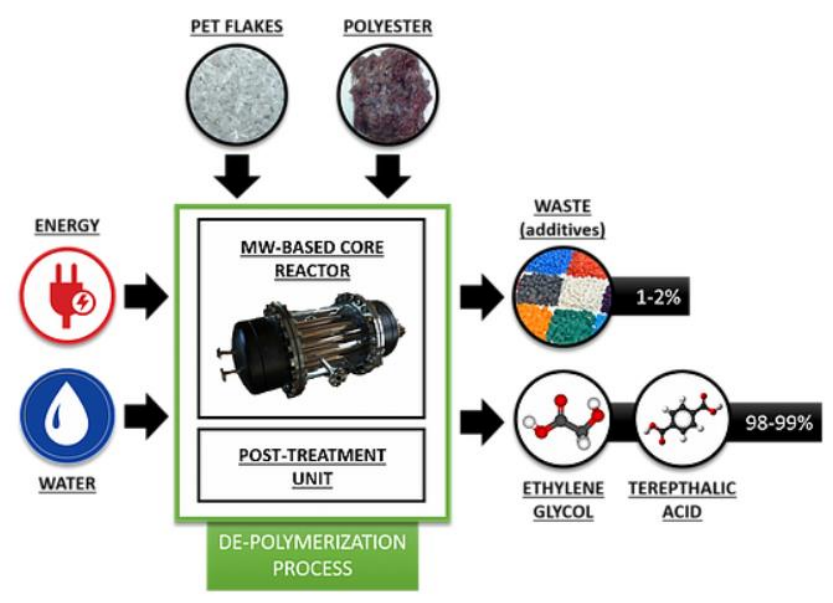

Figure 1. DEMETO's Core Reactor.

Source: https://www.demeto.eu/project

Table 1 shows the main consumers of this technology and the economic benefits obtained from the implementation.

Table 1.

Economic benefit from the introduction of DEMETO technology.

\begin{tabular}{lll}
\hline Main target audience & Justification & Economic benefit \\
\hline Plastic manufacturers & $\begin{array}{l}\text { Reduction of prices for raw materials, lower } \\
\text { volatility of the oil and gas market during } \\
\text { supplies, obtaining a ready-to-polymerize } \\
\text { material }\end{array}$ & $\begin{array}{l}\text { Sale of recycled PET, } \\
\text { increase in production by } \\
\text { about 2 times }\end{array}$ \\
$\begin{array}{l}\text { Waste recycling plants } \\
\text { (using mechanical }\end{array}$ & Ability to recycle non-ferrous waste & $\begin{array}{l}\text { Profitable processing of } \\
\text { recycling) }\end{array}$ \\
Waste collectors & $\begin{array}{l}\text { Diversification of waste sources, vertical } \\
\text { integration at a step in the value chain }\end{array}$ & $\begin{array}{l}\text { Ensuring profitable } \\
\text { recycling of polyester }\end{array}$ \\
Clothing manufacturers & $\begin{array}{l}\text { Reduced raw material price, ability to recycle } \\
\text { industrial waste (polyester) }\end{array}$ & $\begin{array}{l}\text { Increasing brand value, } \\
\text { strengthening the } \\
\text { company's image }\end{array}$ \\
\hline
\end{tabular}

Source: Received by the author

In addition to the economic effect of the introduction, which involves cost reduction of the new goods production process, potential increase in profits, there is also the environmental effect. It includes saving energy used in production, reduction of emissions of harmful substances into the atmosphere, and, consequently, reduction of the negative impact on nature. (Table 2) 
Table 2.

Energy costs saving due to introduction of DEMETO technology.

\begin{tabular}{|c|c|c|}
\hline Indicator & $\begin{array}{l}\text { Mechanical } \\
\text { processing }\end{array}$ & $\begin{array}{l}\text { Recycling using a } \\
\text { microwave reactor }\end{array}$ \\
\hline $\begin{array}{l}\text { The need for non-renewable energy sources } \\
\text { (MJ / kg PET) }\end{array}$ & 66.3 & 21.3 \\
\hline Global Warming Potential $\left(\mathrm{kg} \mathrm{CO}_{2} / \mathrm{kg}\right.$ PET$)$ & 2.08 & 1.28 \\
\hline Acidification $\left(\mathrm{kg} \mathrm{SO}_{4} / \mathrm{kg} \mathrm{PET}\right)$ & 0.00763 & 0.00571 \\
\hline $\begin{array}{l}\text { Eutrophication (saturation of water bodies with } \\
\text { biogenic elements) }\left(\mathrm{kg} \mathrm{PO}_{4} / \mathrm{kg} \text { PET) }\right.\end{array}$ & 0.00225 & 0.00239 \\
\hline
\end{tabular}

Source: Received by the author

Thus, the use of microwave radiation is able to ensure the unlimited life of PET, allowing it to return to its constituent elements (ethylene glycol, terephthalic acid) without destroying materials and, therefore, it will be possible to recycle any types of plastic waste, and in addition, textile fibers consisting of polyester.

Ultimately, using the technology offered by Italian scientists, the process of recycling plastic waste from the moment of collection to the production of fabric for sewing clothes will consist of the following stages:

1. plastic waste collection from places of direct accumulation;

2. waste sorting;

3. primary cleaning;
4. pressing;

5. grinding (granulation);

6. re-cleaning;

7. granulate drying;

8. granulate loading into a microwave reactor;

9. obtaining polyethylene terephthalate (liquid, viscous mass);

10. loading the mass into a spinneret assembly to obtain filaments;

11. loading the yarn into a spinning machine to obtain fabric;

12. sewing clothes from ready-made fabric.

Special conditions are required to implement such a technology. The conditions necessary for the effective implementation of a new technology for waste processing and recycling are shown in Table 3.

Table 3.

Conditions required for the introduction of new technologies for plastics processing.

\begin{tabular}{|c|c|}
\hline ion & Description / implementation method \\
\hline 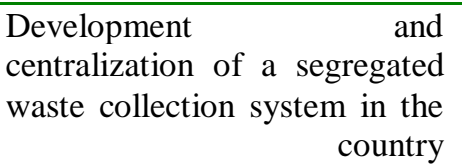 & $\begin{array}{l}\text { Legislative consolidation of the rules for the segregated waste } \\
\text { collection and fines for non-compliance with these rules, the } \\
\text { allocation of funds for the purchase of containers, control and } \\
\text { monitoring of the implementation of the bill. }\end{array}$ \\
\hline $\begin{array}{l}\text { Accounting of produced and } \\
\text { recycled plastic }\end{array}$ & $\begin{array}{r}\text { Accounting of the amount of produced and recycled plastic, the } \\
\text { amount of plastic waste from various activities }\end{array}$ \\
\hline $\begin{array}{c}\text { Creation of plastic waste } \\
\text { collection points }\end{array}$ & $\begin{array}{l}\text { In order to save money, such points can be equipped on the basis of } \\
\text { large supermarkets and hypermarkets in the form of separate racks for } \\
\text { waste collection. }\end{array}$ \\
\hline $\begin{array}{r}\text { Construction of new waste } \\
\text { processing plants }\end{array}$ & Each region of the country must have at least 2 waste processing plants \\
\hline $\begin{array}{l}\text { Improvement of technical } \\
\text { equipment of operating sewing } \\
\text { factories }\end{array}$ & $\begin{array}{r}\text { Purchase of microwave reactors (hereinafter }-\mathrm{MWR} \text { ) and their } \\
\text { installation }\end{array}$ \\
\hline $\begin{array}{r}\text { Training and retraining of } \\
\text { personnel }\end{array}$ & Training to operate the MWR, new workforce recruiting \\
\hline
\end{tabular}

Source: Received by the author

Thus, upon creation of a number of conditions, it will become possible to implement the idea of plastic recycling by the method of Italian scientists, and the main goals of introducing this development will be achieved: energy saving, reduction of harmful emissions into the atmosphere, sustainable consumption and production. The introduction of a new method of 


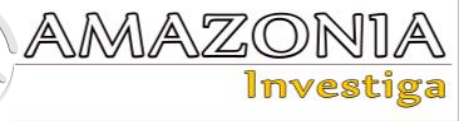

plastic waste processing into the production chain of textile factories will ensure the creation of an innovative system able to minimize the amount of landfilled waste. Moreover, it will ensure resource conservation, the re-use of recycled plastic waste as a secondary raw material for textile production and will make it possible for a country to reduce the share of imported textiles and bring considerable profit from production by cost reduction.

\section{Conclusions}

Plastic has become the most abundant material produced by humans, and the damage caused by plastic emissions may soon result in a global environmental disaster. Solving the problem of environmental pollution by production and consumption waste is a complex of serious problems that require a systematic and urgent solution. That is why it is very important to think about the issue of recycling plastic waste, while making the choice fall on the safest of the recycling methods.

Today, there are many methods of plastic recycling, but many of them are also harmful to the environment. The proposed idea of recycling plastic and using it as a recyclable material for the production of clothing is an example of a safe and useful way to deal with plastic pollution. The use of plastic in the production of clothing can significantly reduce the amount of garbage in the waters of the world's oceans, harmful emissions of toxins into the atmosphere, as well as reduce costs in the production of clothing through the use of recycled materials.

The following is required to implement such an idea:

- effective legislative regulation, the creation of a number of laws and acts in order to stimulate the implementation of ecoinnovations, and reduce environmental pollution;

- competent environmental policy, strategic planning in the field of innovations aimed at preventing environmental pollution;

- development and implementation of government programs and projects aimed at maintaining and shaping the environmental market in Russia.

The experience of Western countries in the disposal of plastic waste is a clear example of the successful introduction of recyclable materials into production. This can be confirmed by the fact that most of the plastic waste in these countries is now being recycled to create new products and materials.

Mankind objectively needs new technical solutions in all branches of production, which would be aimed both at developing business and making a profit, as well as at preserving and protecting the environment.

\section{Bibliographic references}

BASF (2021). BASF invests in chemical recycling. Reinforced Plastics, 65 (4), 161. https://doi.org/10.1016/j.repl.2021.06.030

Buciuni, G., \& Pisano, G. (2021). Variety of Innovation in Global Value Chains. Journal of World Business, 56 (2), 101167. https://doi.org/10.1016/j.jwb.2020.101167

Chaturvedi, S., Yadav, B.P., Siddiqui, N.A., Chaturvedi, S.K. (2020). Mathematical modelling and analysis of plastic waste pollution and its impact on the ocean surface. Journal of Ocean Engineering and Science, $5 \quad$ (2), 136-163. https://doi.org/10.1016/j.joes.2019.09.005

Chen, Z., Wang, Y., Cheng, Y., Wang, X., Tong, S., Yang, H., \& Wang, Z. (2020). Efficient biodegradation of highly crystallized polyethylene terephthalate through cell surface display of bacterial PETase. Science of The Total Environment, 709, 136138. https://doi.org/10.1016/j.scitotenv.2019.136 138

Defeuilley, C., \& Lupton, S. (1998). The future place of recycling in household waste policy: the case of France. Resources, Conservation and Recycling, 24 (3-4), 217-233. https://doi.org/10.1016/S09213449(98)00018-4

Fadhilah, Z., \& Ramayah, T. (2012). Behind the Green Doors: What Management Practices Lead to Sustainable Innovation? Procedia Social and Behavioral Sciences, 65, 247-252. https://doi.org/10.1016/j.sbspro.2012.11.118

González-Torre, P.L., Adenso-Díaz, B., \& Ruiz-Torres, A. (2003). Some comparative factors regarding recycling collection systems in regions of the USA and Europe. Journal of Environmental Management, 69(2), 129-138. https://doi.org/10.1016/S03014797(03)00109-9

Hage, O., Söderholm, P., \& Berglund, C. (2009). Norms and economic motivation in household recycling: Empirical evidence from Sweden. Resources, Conservation and Recycling, 53(3), 155-165. 
https://doi.org/10.1016/j.resconrec.2008.11.0 03

Honma, S., \& Hu, J.-L. (2021). Cost efficiency of recycling and waste disposal in Japan. Journal of Cleaner Production, 284, 125274. https://doi.org/10.1016/j.jclepro.2020.12527 4

Ishalina, O.V., Lakeev, S.N., Minnigulov, R.Z., \& Majdanova, I.O. (2015). Analysis of polyethylene terephthalate waste recycling methods. Production and use of elastomers, (3), 39-48 (in Russian). https://cyberleninka.ru/article/n/analizmetodov-pererabotki-othodovpolietilentereftalata

Kantz, O. (2000). Volvo's holistic approach to environmental strategy. Corporate Environmental Strategy, 7(2), 156-169. https://doi.org/10.1016/S10667938(00)00047-6

Kim, B., Won Kim, S., and Park, K.S. (2021). Promoting supplier's environmental innovation via emission taxation. International Journal of Production Economics, 240, 108240. https://doi.org/10.1016/j.ijpe.2021.108240

Kinnaman, T.C., Shinkuma, T., \& Yamamoto, M. (2014). The socially optimal recycling rate: Evidence from Japan. Journal of Environmental Economics and Management, $\quad 68(1), \quad$ 54-70. https://doi.org/10.1016/j.jeem.2014.01.004

Kumamaru, H., \& Takeuchi, K. (2021). The impact of China's import ban: An economic surplus analysis of markets for recyclable plastics. Waste Management, 126, 360-366. https://doi.org/10.1016/j.wasman.2021.03.02 7

Latham, K. (2021). The world's first 'infinite' plastic. BBC (website). https://www.bbc.com/future/article/2021051 0-how-to-recycle-any-plastic

Lee, J., Kwon, E.E., Lam, S.S., Chen, W.-H., Rinklebe, J., \& Park, Y.-K. (2021). Chemical recycling of plastic waste via thermocatalytic routes. Journal of Cleaner Production, 321, 128989.

https://doi.org/10.1016/j.jclepro.2021.12898 9

Lonca, G., Lesage, P., Majeau-Bettez, G., Bernard, S., \& Margni, M. (2020). Assessing scaling effects of circular economy strategies: A case study on plastic bottle closed-loop recycling in the USA PET market. Resources, Conservation and Recycling, 162, 105013. https://doi.org/10.1016/j.resconrec.2020.105 013

Mastellone, M.L. (2019). A feasibility assessment of an integrated plastic waste system adopting mechanical and thermochemical conversion processes. Resources, Conservation \& Recycling: X, 4, 100017. https://doi.org/10.1016/j.rcrx.2019.100017

Matsumoto, S. (2011). Waste separation at home: Are Japanese municipal curbside recycling policies efficient? Resources, Conservation and Recycling, 55 (3), 325-334. https://doi.org/10.1016/j.resconrec.2010.10.0 05

Mattsson, C.H., Berg, P.E.O., \& Clarkson, P.A. (2003). The development of systems for property close collection of recyclables: experiences from Sweden and England. Resources, Conservation and Recycling, 38(1), 39-57. https://doi.org/10.1016/S09213449(02)00095-2

Moinard, V., Levavasseur, F., \& Houot, S. (2021). Current and potential recycling of exogenous organic matter as fertilizers and amendments in a French peri-urban territory. Resources, Conservation and Recycling, 169, 105523. https://doi.org/10.1016/j.resconrec.2021.105 523

Nusratullin, I., Sergeev, N., Kuznetsov, M., Sheina, A., \& Shubtsova, L. (2020). Industrial development under sanctions pressure: evidence from Russia. Amazonia Investiga, $\quad 9(28), \quad 465-474$. https://doi.org/10.34069/AI/2020.28.04.51

Nusratullin, I., Yarullin, R., Ismagilova, T., Eremeeva, O., Ermoshina, T. (2021). Economic and financial results of the USA and the European Union sanctions war against Russia: first results. Cuestiones Politicas, $39 \quad$ (68), 251-272. https://doi.org/10.46398/cuestpol.3968.16

Otegbeye, M., Abdel-Malek, L., Hsieh, H.N., \& Meegoda, J.N. (2009). On achieving the state's household recycling target: A case study of Northern New Jersey, USA. Waste Management, 29 (2), 647-654. https://doi.org/10.1016/j.wasman.2008.06.04 1

Parker, L. (2018). Here's how much plastic trash is littering the earth. National Geographic Society (website). https://www.nationalgeographic.com/science /article/plastic-produced-recycling-wasteocean-trash-debris-environment

Patel, M., von Thienen, N., Jochem, E., \& Worrell, E. (2000). Recycling of plastics in Germany. Resources, Conservation and Recycling, $29 \quad$ (1-2), 65-90. https://doi.org/10.1016/S09213449(99)00058-0 


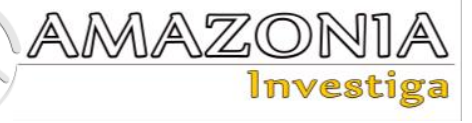

Peeters, B., Kiratli, N., \& Semeijn, J. (2019). A barrier analysis for distributed recycling of $3 \mathrm{D}$ printing waste: Taking the maker movement perspective. Journal of Cleaner Production, 241, 118313. https://doi.org/10.1016/j.jclepro.2019.11831 3

Pérez-López, G., Prior, D., Zafra-Gómez, J.L., \& Plata-Díaz, A.M. (2016). Cost efficiency in municipal solid waste service delivery. Alternative management forms in relation to local population size. European Journal of Operational Research, 255 (2), 583-592. https://doi.org/10.1016/j.ejor.2016.05.034

Provin, A.P., Dutra, A.R. de A., Machado, M.M., Cubas, A.L.V. (2021). New materials for clothing: Rethinking possibilities through a sustainability approach - A review. Journal of Cleaner Production, 282, 124444. https://doi.org/10.1016/j.jclepro.2020.12444 4

Ragaert, K., Delva, L., \& van Geem, K. (2017). Mechanical and chemical recycling of solid plastic waste. Waste Management, 69, 24-58. https://doi.org/10.1016/j.wasman.2017.07.04 4

Rickert, J., Cerdas, F., \& Herrmann, C. (2020). Exploring the environmental performance of emerging (chemical) recycling technologies for post-consumer plastic waste. Procedia CIRP, $\quad 90, \quad 426-431$. https://doi.org/10.1016/j.procir.2020.01.111

Salmenperä, H. (2021). Different pathways to a recycling society - Comparison of the transitions in Austria, Sweden and Finland. Journal of Cleaner Production, 292, 125986. https://doi.org/10.1016/j.jclepro.2021.12598 6

Schüch, A., Morscheck, G., Lemke, A., \& Nelles, M. (2016). Bio-waste Recycling in Germany - Further Challenges. Procedia Environmental Sciences, 35, 308-318. https://doi.org/10.1016/j.proenv.2016.07.011
Soltani, N.S., Taylor, M.P., \& Wilson, S.P. (2021). Quantification and exposure assessment of microplastics in Australian indoor house dust. Environmental Pollution, 283, 117064. https://doi.org/10.1016/j.envpol.2021.11706 4

Steinhorst, J., \& Beyerl, K. (2021). First reduce and reuse, then recycle! Enabling consumers to tackle the plastic crisis - Qualitative expert interviews in Germany. Journal of Cleaner Production, $\quad 313$, 127782. https://doi.org/10.1016/j.jclepro.2021.12778 2

Ullah, S., \& Nasim, A. (2021). Do firm-level sustainability targets drive environmental innovation? Insights from BRICS Economies. Journal of Environmental Management, 294, 112754. https://doi.org/10.1016/j.jenvman.2021.1127 54

Wang, Y., Gu, Y., Wu, Y., Zhou, G., Wang, H., Han, H., \& Chang, T. (2020). Performance simulation and policy optimization of waste polyethylene terephthalate bottle recycling system in China. Resources, Conservation and Recycling, 162, 105014. https://doi.org/10.1016/j.resconrec.2020.105 014

Zhang, C., Hu, M., Yang, X., Miranda-Xicotencatl, B., Sprecher, B., Di Maio, F., Zhong, X., \& Tukker, A. (2020). Upgrading construction and demolition waste management from downcycling to recycling in the Netherlands. Journal of Cleaner Production, 266, 121718. https://doi.org/10.1016/j.jclepro.2020.12171 8

Zhang, S. (2017). Half of all plastic that has ever existed was made in the past 13 years. The Atlantic (website). https://www.theatlantic.com/science/archive/ 2017/07/plastic-age/533955/ 